\title{
OS MEMES VÃO ALÉM DO HUMOR: UMA LEITURA MULTIMODAL PARA A CONSTRUÇÃO DE SENTIDOS
}

\author{
Anderson Guerreiro* \\ Neiva Maria Machado Soares ${ }^{\star *}$
}

\begin{abstract}
RESUMO: $O$ advento das novas mídias digitais trouxe para o ambiente cibernético inovadoras maneiras de se comunicar e usar a língua, passando esta a ser mais dinâmica e visual. Em paralelo a isso, novos gêneros surgem como resultado de alterações no ciberespaço. O meme é um dentre estes e destaca-se por sua acentuada presença nas redes sociais. Avaliando a sua importância no contexto atual, buscamos analisar a configuração discursivo-visual presente neste gênero digital. Tomamos como objeto de análise dois memes, escolhidos por terem sido bastante difundidos nas redes sociais e por conduzirem práticas sociais acerca da vida contemporânea. As categorias analíticas empregadas são as da Teoria da Semiótica Social Multimodal (TSSM): Adotamos os pressupostos de Kress, Leite-Garcia e van Leeuwen (2002) quanto à concepção semiótica dos textos multimodais em seus aspectos externos, considerando o momento da produção, a inferência do leitor, a cultura e o contexto social; bem como os da Gramática do Design Visual (GDV), teoria desenvolvida por Kress e van Leeuwen (2006), que analisa os significados representacional, interativo e composicional, no que se refere à construção de sentido, tanto humorístico quanto crítico, considerando os participantes apresentados nas imagens, a interação com o observador e a composição imagética. A análise evidenciou que esses gêneros estão difundidos nas redes sociais, servindo tanto para divulgação de temáticas cotidianas quanto para críticas pontuais sobre situações vivenciadas por inúmeras pessoas.
\end{abstract}

PALAVRAS-CHAVE: Gênero Digital. Multimodalidade. Discurso-visual.

\section{Considerações Iniciais}

A linguagem, como sistema de comunicação, sempre foi a base das interações e das relações humanas. Como um complexo mutável, habitualmente foi propensa a transmutações sucedidas ao decorrer dos tempos. A partir do advento da pósmodernidade, e consequentemente $o$ da era digital, diversas práticas e realizações sociais vêm sofrendo constantes modificações, com isso a língua passa ser mais dinâmica, versátil, flexível e atrativa. O ambiente digital viabiliza diversas ferramentas que a tornam mais acessível a um público que aspira por materiais cada

\footnotetext{
*Universidade do Estado do Amazonas, Brasil. E-mail: agds.anderson@gmail.com

** Universidade do Estado do Amazonas, Brasil. E-mail: nemsoa@hotmail.com

(c) $\mathrm{EY}$

Esta obra está licenciada com uma licença Creative Commons - Atribuição 4.0 Internacional.

Texto Digital, Florianópolis, Santa Catarina, Brasil, v. 12, n. 2, p. 185-208, jul./dez. 2016. ISSNe: 1807-9288.
} 
vez mais dinâmicos e ao mesmo tempo com conteúdo. Os domínios digitais carregam, agora, não apenas textos verbais, como também imagéticos, objetos em movimento, sons, cores e disposições dos textos. Essa configuração ocorre devido à organização multimodal dos textos contemporâneos. Tal como a multimodalidade conduziu um novo olhar sobre o trato de questões linguísticas, também o surgimento de novos gêneros resulta de transformações em práticas sociais. As diversas modalidades textuais e sua dinamicidade convergem à criação de gêneros característicos do ambiente virtual, especialmente nas redes sociais, tais como o tweet, o gif e o meme. Este último nos chama atenção, visto que são criações dos próprios usuários que mesclam uma situação - que obteve destaque nas mídias e, de certa forma, tornou-se memorável e viral - com diversas frases cotidianas, que juntas complementam-se e acabam tendo um significado humorístico e irônico. Presente nas redes sociais, é destinado, comumente, para efeito de humor, porém, percebe-se também uma crítica social, política e cultural.

Com isso, temos como objetivo, neste trabalho, analisar o discurso deste gênero digital, por meio das categorias da Teoria da Semiótica Social Multimodal (TSSM): com a Gramática do Design Visual (GDV) exploraremos os aspectos internos dos memes; por meio dos pressupostos de Kress, Leite-Garcia e van Leeuwen, relativos à concepção semiótica dos textos multimodais, examinaremos os aspectos internos. Com isso, buscamos revelar como ocorre a construção de sentido, tanto humorístico quanto crítico, levando em consideração os personagens presentes, a interação com o observador e a composição das imagens, bem como o momento da produção, a inferência do leitor, a cultura e o contexto social. Esses aspectos podem nos auxiliar nas observações das ideologias intrínsecas no gênero, bem como as críticas que trazem e que, diversas vezes, parecem-nos alheias.

A análise à luz da TSSM é importante, pois o gênero analisado condensa diversos modos semióticos de representação discursiva. Teremos ainda, como suporte teórico, Bauman (2001) pela abordagem acerca das modificações pós-modernas, principalmente, na internet; Dionísio (2006), Vieira (2007) e Kress e van Leeuwen (2006 [1996]), com as propostas para análise de textos multimodais, bem como a Gramática do Design Visual (GDV); Nascimento et al. (2001), por trabalharem a 
necessidade do multiletramento digital; à abordagem do meme como gênero discursivo e digital, cotejaremos a perspectiva de Marcuschi (2008) e Bakhtin (2003), mostrando como os avanços tecnológicos incitam à construção de novos gêneros, sendo o meme um destes.

\section{0 advento da pós-modernidade, a emergência tecnológica e as mudanças linguísticas no ciberespaço}

A pós-modernidade, como sistema contemporâneo de modo de vida em sociedade, trouxe grandes rupturas e novas tendências associadas às diversas práticas e manifestações linguísticas e sociais. A linguagem e a comunicação, nesse contexto, não ficaram imunes às modificações que ocorreram paulatinamente desde o estabelecimento da TV e do cinema, nos anos 60. Martino (2015) traz alguns conceitos-chave que caracterizam esse sistema em crescimento, sendo eles: insegurança, informação, fluxo e instabilidade. Para o autor, esses elementos são pertinentes numa sociedade cada vez mais digitalizada, versátil e emergente.

Em uma mesma linha de pensamento, temos o sociólogo Zygmunt Bauman que afirma ser imprudente negar, ou mesmo subestimar, a profunda mudança que o advento da "modernidade fluida" produziu na condição humana (2001, p.15). Sobre os meios de comunicação de massa, assevera que exercem formidável poder sobre a imaginação popular, coletiva e individual, em que imagens "mais reais que a realidade" em telas ubíquas estabelecem padrões da realidade e de sua avaliação, e também a necessidade de se tornar mais palatável a realidade vivida (BAUMAM, 2001, p. 99).

Observamos que as mutações mais radicais e desafiadoras foram dadas com o advento da internet. Siegel (apud MARTINO, 2015, p. 127) aponta para a impossibilidade de pensar "a internet sem estabelecer uma relação com seu 'significado cultural'” nas práticas sociais cotidianas. O autor entende que as tecnologias afetam e relacionam diretamente as diversas atividades realizadas pelos indivíduos. Não diferente, McLuhan (2007 [1969]), bem antes do advento da internet, enunciou que as profundas alterações sociais se originaram concomitantemente aos 
processos comunicativos, tais como a invenção da imprensa, a máquina de escrever, o rádio e a televisão. Hoje, particularmente, ao observar o surgimento e o estabelecimento da internet, verificamos o mesmo processo observado anteriormente. Rajagopalan (2013, p. 50) descreve que na web "a escrita, a fala e a imagem se mesclam de certa forma, até pouco tempo atrás, impensável"; já Dionísio (2011) aponta que as novas tecnologias trouxeram facilidades na criação de novas imagens, novos layouts.

Assim, as práticas da linguagem na pós-modernidade constituem-se, principalmente, de modo multimodal, ou seja, diversos modos semióticos fundem-se para criar novos efeitos aos discursos, aliados juntamente aos novos layouts, fontes textuais e softwares disponíveis no ciberespaço. Haja vista as frequentes dúvidas quanto aos modos semióticos existentes, Soares (2016) ilustra, com base nas ideias de C. Jewit, aqueles mais recorrentes, conforme aponta a Figura 1.

Fig. 1 - Comunicação e representação - modos comunicativos

\section{GESTO}

\section{LINGUAGEM}

IMAGEM

POSTURA

OLHAR

Fonte: SOARES, 2016.

No espaço digital, é recorrente o uso de imagens com textos, textos em movimento, áudios agrupados com imagens e textos. Esta talvez seja a principal mudança recente na forma de comunicações, presente especialmente nas redes sociais e bastante perceptíveis na contemporaneidade. 


\subsection{Os gêneros emergentes: reflexos das mudanças comunicativas}

Como reflexo dessas transmutações nas práticas da linguagem, indiscutivelmente, novos gêneros discursivos aparecem no ambiente cibernético, como os memes, os gifs e os tweets.

Ao discutir gêneros discursivos, Marcuschi (2008) considera que tais manifestações não são contemporâneas, ao contrário, vêm sendo estudadas desde a Antiguidade, em obras como, por exemplo, de Platão e Aristóteles. Porém, apenas no século XX, ganharam destaque com Mikhail Bakhtin, o qual influenciou diversos pesquisadores da área, levando esta temática a uma discussão mais profunda. Bakhtin analisou e concluiu que todo e qualquer modo de comunicação, seja verbal ou não-verbal, constitui-se necessariamente pela presença do que convencionou chamar de gêneros discursivos. Para ele, gêneros são "entendidos como domínios ideológicos que dialogam entre si e produzem, em cada esfera, formas relativamente estáveis de enunciados" (2003, p. 42), ou seja, segundo esse pensamento, a utilização da língua é feita sempre por meio de um determinado gênero.

Compreendemos que, a partir do advento da internet, diversos gêneros sofreram mudanças e alguns se remodelaram, como no caso da carta que se deslocou do ambiente físico para o digital e está presente na troca de e-mails. Ainda, novos foram elaborados e produzidos, haja vista a necessidade de interação nos moldes do ambiente digital, com uma leitura mais leve, rápida e visual. Também denominados "gêneros digitais", em razão de surgirem nesses espaços e neles predominarem. Dentre eles, um nos chama atenção, pela sua dinamicidade, multimodalidade e os elementos que vão além de sua animação: o meme.

\section{Meme: manifestações e peculiaridades deste gênero digital}

Os primeiros trabalhos relativos a esse novo gênero que ora se manifesta no ciberespaço apontam que o surgimento do termo tem origem no campo da Biologia, especificamente, nos estudos sobre genética. Richard Dawkins, biólogo e escritor britânico, em 1976, relacionou o termo "meme" à capacidade dos genes em replicarem-se e reproduzirem-se numa seleção natural. O pesquisador apropriou-se 
do termo "mimeme" que tem origem grega e expressa tudo aquilo que pode ser imitado, com isso, ele associou tal prática ao fato de os genes replicarem-se e transmitirem informações sobre os aspectos genéticos do ser humano (CANDIDO e GOMES, 2015). O momento em que o termo começou a ser utilizado na internet é impreciso. Araújo (2013) destaca que, por volta dos anos 2000, a palavra ganhou destaque em um evento que discutia acontecimentos e assuntos virais na web. A partir daí, ganhou uma nova concepção semântica mais próxima do que temos na atualidade, e indica tudo aquilo que se tornou viral na web, ou seja, que se propagou e se popularizou muito depressa no ambiente cibernético, seja por meio de compartilhamento ou cópias. Para Martino (2015, p. 177-178), “imagens, sons, gestos, palavras, melodias, jeitos de se vestir e até mesmo elementos complexos como crenças ou rituais se disseminam pela sociedade na forma de meme". Ele ainda cita Shifman (2013), que no livro "Memes in digital culture", define meme como a facilidade de manipulação e divulgação de materiais na web, transformando-o assim em um fenômeno cultural. Corroborando, Carvalho e Kramer (2013, p. 86) apontam que os memes "são modismos usados durante um período de tempo, muito populares nas comunicações por redes".

Observamos, contudo, que esses conceitos, até então apresentados, assim como desde sua origem, ainda vêm sendo remodelados. O referido termo deixou (ou ainda está deixando) de trazer o significado referente a qualquer coisa que se espalha no ciberespaço. A palavra agora faz referência, especificamente, a algumas imagens que ora são postadas, sobretudo, nas redes sociais (Figura 2), sendo elas criações dos próprios usuários que mesclam uma situação - que obteve destaque nas mídias e de certa forma tornou-se memorável - com diversas frases cotidianas, que juntas se complementam e acabam tendo um significado, comumente humorístico. 
Fig. 2 - Exemplo de um meme no perfil Sky FM do Twitter

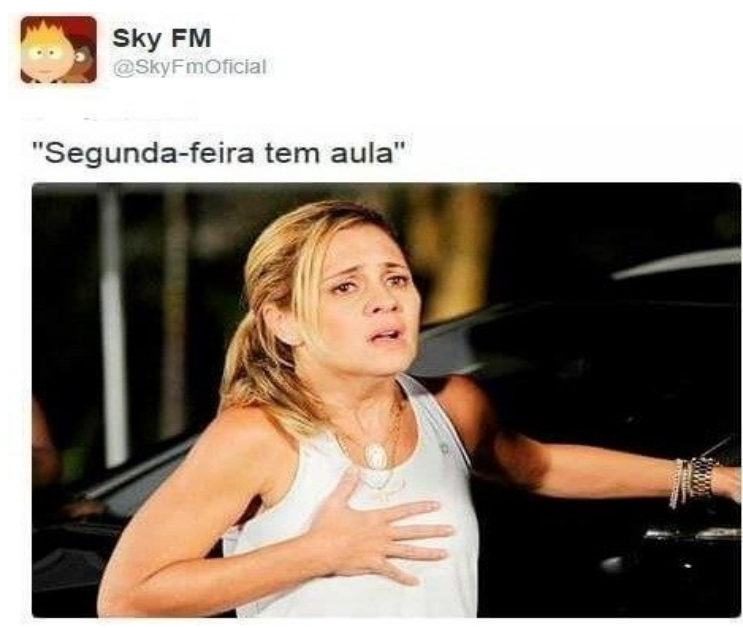

Fonte: Twitter, 2016.

Como exemplo, a Figura 2 traz a imagem da personagem interpretada pela atriz Adriana Esteves, que ficou bastante conhecida na telenovela Avenida Brasil (Rede Globo, 2012), criando sentido ao texto apresentado.

Importante destacar que os memes são elaborados por intermédio de uma imagem, retirada de uma cena do cotidiano, e de um texto, extraído de um outro contexto, mas na configuração final do meme adquire uma significação característica. Outra questão observada é que não há preocupação do produtor dessas imagens quanto ao design visual, pois são produzidas de modo colaborativo e com autoria não divulgada. Candido e Gomes (2015, p. 1298) ressaltam a simplicidade dos memes que "podem ser produzidos com os mais básicos programas de edição, pois o objetivo não é arte, mas a situação que deseja comunicar, sempre com o fundo de comicidade". Martino (2015, p. 178) concorda ao afirmar que "qualquer pessoa com conhecimentos rudimentares de edição de imagem digital pode, potencialmente, se apropriar de uma ideia, modificá-la e compartilhá-la", características da produção desse gênero.

Candido e Gomes (2015, p. 1298), ao analisá-los, apontam ainda que "retratam geralmente situações do dia a dia de forma cômica e satírica". Com isso, constatamos que é destinado não apenas para efeito de humor, mas também a uma crítica social, política e cultural, satirizando, dessa forma, diversos fatos cotidianos, 
sendo considerado, em grande parte, um protesto virtual. A seguir, retrataremos das principais características atribuídas ao gênero:

Tabela 1 - As características recorrentes dos memes

\begin{tabular}{|c|c|c|c|}
\hline Objetivo & $\begin{array}{c}\text { Conteúdo } \\
\text { Proposicional }\end{array}$ & Forma & Função Social \\
\hline $\begin{array}{l}\text { - Interagir com os } \\
\text { participantes } \\
\text { (representados e } \\
\text { interativos) }\end{array}$ & $\begin{array}{c}\text { - Registrar histórias } \\
\text { sociais e culturais, } \\
\text { contextos atuais }\end{array}$ & $\begin{array}{l}\text { - Multimodal } \\
\text { (incorporação } \\
\text { de diferentes } \\
\text { modos } \\
\text { semióticos) }\end{array}$ & $\begin{array}{c}\text { - Mostrar ideologias } \\
\text { sociais } \\
\text { incorporadas }\end{array}$ \\
\hline
\end{tabular}

Fonte: Elaboração dos autores, com base nos teóricos citados e nas características dos memes

A abordagem, a partir de então, focalizará o último elemento apontado no quadro acima: a função social. Notamos que a compreensão total deste gênero abarca, além do sentido humorístico, o crítico, sendo necessária, não somente a articulação dos signos semióticos e linguísticos para este entendimento, como também a exploração dos significados que vão além do texto, da imagem e do humor por ele produzido.

\section{As contribuições da Gramática do Design Visual}

Dentro desse contexto de novas abordagens semióticas, evidenciamos a teoria de Kress e van Leeuwen (2006), que versa sobre análises imagéticas: a Gramática do Design Visual, doravante GDV. Essa teoria tem sua manifestação no contexto da Linguística Sistêmico-Funcional (LSF), abordagem desenvolvida pelo linguista Michael Halliday na década de 1950. Halliday (1994) observou que, em relação ao contexto situacional de uma comunicação, devem-se levar em consideração, para análise, três variáveis, a saber: o campo, a relação e o modo. A partir daí, surge o conceito de metafunções da linguagem: ideacional, interpessoal e textual. Tomando como base os postulados de Halliday, Kress e van Leeuwen elaboraram a teoria da 
Gramática do Design Visual. Para eles "o que é expresso na linguagem através da escolha entre diferentes classes de palavras e estruturas semânticas, na comunicação visual é expresso pela escolha entre diferentes usos de cores e de estruturas composicionais" (KRESS; van LEEUWEN, 2006, p. 2). O fato é que os textos verbais e as imagens têm estreita relação e aproximação em suas características, estruturas e funcionamento, porém o texto visual, ao contrário dos verbais, não tinham mecanismos para análise que foram operacionalizados pela GDV.

O estudo desenvolvido por Kress e van Leeuwen (2006 [1996]), ancorado nas teorias da LSF, ocupa-se da análise e da descrição, exclusivamente, de imagens, em seu sentido amplo, ou seja, toma como objeto de estudo desde fotografias a diagramas. A GDV procura interpretar as imagens no que diz respeito às suas representações, interações e composição, levando em consideração o contexto situacional e os participantes envolvidos. Dessa forma, busca esclarecer os pontos de vistas e as ideologias intrínsecas à imagem e que, muitas vezes, tornam-se alheias ao observador. A representação da construção e simbolização dos participantes, o contato, a aproximação com o observador, as expressões faciais, os gestos e os movimentos, além das cores, das texturas e da organização estrutural das imagens constituem-se fragmentos relacionados aos três aspectos que estabelecem o corpus de análises da Gramática do Design Visual, a saber, a metafunção representacional, interativa e composicional.

\subsection{O fenômeno da multimodalidade e o multiletramento}

É fato incontestável que a multimodalidade está permanentemente enlaçada às diversas práticas sociais. Como já abordado, o advento das novas tecnologias e da internet trouxe profundas transformações em diversos aspectos sociais. A multimodalidade talvez seja a principal característica dos textos atuais, sobretudo os digitais. Rocco (apud KENSKY, 2003, p. 62) analisa que "o texto eletrônico é um produto verbal diferente, um produto de um novo tempo, vinculado a um novo suporte que atua [...] sobre os processos de apropriação e significação por parte dos leitores. Trata-se de um texto híbrido". Nesse contexto, Kress e van Leeuwen (2006) 
consideram os textos multimodais como aqueles que se utilizam de combinações de diversos códigos semióticos para conduzir significado ao receptor, ou seja, esse fenômeno acontece quando um texto, para transmitir seu conteúdo, emprega pelo menos duas modalidades de comunicação, sendo os mais utilizados o texto e a imagem. Neste caso, "apenas a transmissão dos recursos verbais não se faz suficiente para a construção de um sentido mais global do fato narrado" (DIONÍSIO, 2011, p. 134).

Convém notarmos que, tais como as ações sociais constituem-se como fenômenos multimodais, os gêneros discursivos também. Isso porque, quando produzimos um texto, seja na fala ou na escrita, utilizamos mais de um modo de representação, bem como, palavras e gestos, palavras e entonações, palavras e imagens, palavras e sorrisos etc. (DIONÍSIO, 2011). Todas essas manifestações são modos de constituição dos discursos e que devem ser levadas em consideração. A autora ainda aborda que a multimodalidade ainda se aplica à própria distribuição, estruturação e posição dos textos tanto no papel quanto no computador. Para ela, "tipografia de disposição gráfica são semioticamente significativos para o enquadre semântico-cognitivo" em relação aos textos multimodais (DIONíSIO, 2011, p. 135). Nascimento et al. (2011) partem do princípio de que não há textos monomodais, visto que continuamente utilizam recursos visuais, assim como, distribuição em colunas, em gráficos e em linhas, bem como ao uso de fontes novas, negrito, itálico, isso com o objetivo de acentuar determinados elementos. Assim, observamos que, embora, aparentemente, um texto traga somente uma modalidade, seus arranjos tipográficos, visuais e até mesmo suas fontes textuais e cores constituem-no multimodal, conforme é evidenciado na Figura 3. 
Fig. 3 - Poema do poeta Haroldo de Campos, exemplo de um texto multimodal por sua disposição e estrutura visual, tipicamente usado nas poesias concretas

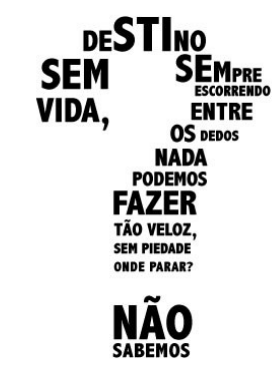

Fonte: COURI, 2013.

Em uma sociedade cada vez mais visual, este fenômeno multimodal encontra aporte e propaga-se muito depressa entre os textos contemporâneos. Kress (2003, p. 1) aponta que "a língua enquanto escrita será progressivamente suplantada pela imagem em diversas áreas da comunicação pública". Com isso, observamos que cada recurso semiótico não deve ser analisado separadamente dos demais, pois cada qual cumpre um papel na construção do sentido do todo, tendo eles uma relação independente.

As considerações a respeito da teoria multimodal e as perspectivas de análise contribuem para uma nova forma de letramento: o visual, a ser retomado em seções posteriores. Não apenas a estrutura interna das imagens, seus enquadramentos, seleção de cores e distribuição dos elementos são itens necessários a serem lidos e analisados, como também os pressupostos que partem de uma análise que vai além desses itens e chega até os elementos sociais e culturais adjuntos a esses textos. Vieira (2007, p. 53-4) assinala quatro itens a serem essencialmente analisados em textos multimodais, são eles: "o discurso, o design, a produção e a distribuição".

Dessa forma, a competência comunicativa multimodal faz-se necessária em nossa cultura atual em que prepondera o visual. Os Parâmetros Curriculares Nacionais (BRASIL, 2006, p. 29) apontam a necessidade de essa atividade ser levada à sala de aula, podendo o aluno: 
Se ater ao letramento da letra, mas deve, isso sim, abrir-se para os múltiplos letramentos que, envolvendo uma enorme variação de mídias, constroem-se forma multissemiótica e híbrida (...). Reitera-se que essa postura é condição para confrontar o aluno com a prática da linguagem que o levem a formar-se para o mundo do trabalho e para cidadania com respeito pelas diferenças no modo do fazer sentido.

Compreendemos, portanto, que o letramento engloba os símbolos gráficos e também pelos múltiplos formatos semióticos a que somos submetidos no dia a dia, desde os mais simples, tais como os gestos naturais ao despertar pela manhã, a oração, a música no rádio, a notícia do jornal e os emotions, presentes em nosso cotidiano. Essa perspectiva plural de formatação e organização textual e discursiva remete ao conceito de multiletramento. Para Dionísio (2011, p. 131):

\begin{abstract}
A noção de letramento como habilidade de ler e escrever não abrange todos os diferentes tipos de representação do conhecimento existentes em nossa sociedade. $\mathrm{Na}$ atualidade, uma pessoa letrada deve ser uma pessoa capaz de atribuir sentidos a mensagens oriundas de múltiplas fontes de linguagem, bem como ser capaz de produzir mensagens, incorporando múltiplas fontes de linguagem.
\end{abstract}

Os pressupostos da GDV contribuem neste sentido, por trazerem ferramentas que contribuem para análise e interpretação de textos multimodais. A sua base teórica é Teoria da Semiótica Social Multimodal (TSSM). Essa linha de investigação da semiótica diferencia-se da tradicional, visto que não abarca, em suas análises, somente a estrutura e os aspectos internos do texto ${ }^{1}$, como também parte para análises relacionadas ao contexto sociocomunicativo, às experiências de mundo que, de certa forma, são envolvidos na construção do texto e necessários para compreendê-los. Vieira $(2007$, p. 53) ressalta que os interesses dessa teoria estão "nas origens sociais e na produção dos modos e na sua recepção". Na sequência, iniciaremos a análise à luz dos pressupostos de Kress, Leite-Garcia e van Leeuwen e da GDV, considerando os aspectos externos e internos da leitura multimodal.

\footnotetext{
${ }^{1}$ Referimo-nos "textos", a partir de agora, a toda forma de comunicação, seja ela verbal, não verbal e/ou multimodal.
}

Texto Digital, Florianópolis, Santa Catarina, Brasil, v. 12, n. 2, p. 185-208, jul./dez. 2016. ISSNe: 1807-9288. 


\section{Análise dos memes: aspectos externos e internos em uma leitura multimodal}

Os mecanismos semióticos de análise de textos multimodais constituem-se de variadas formas e por inúmeros teóricos desse campo. Kress, Leite-Garcia e van Leeuwen elaboraram alguns dos pressupostos para entender e analisar os diversos textos multimodais contemporâneos no que diz respeito aos seus aspectos externos, levando em consideração o momento da produção do texto, a inferência do leitor, a cultura e o contexto social. A partir da teoria da GDV, analisaremos os aspectos internos relativos aos memes, a fim de evidenciar, além do humor, a ideologia revelada em tais imagens. A seguir, apresentamos os dois memes, retirados de redes sociais, que compõem o corpus de análise.

Fig. 4 - Meme retirado do Facebook relativo à prova do ENEM

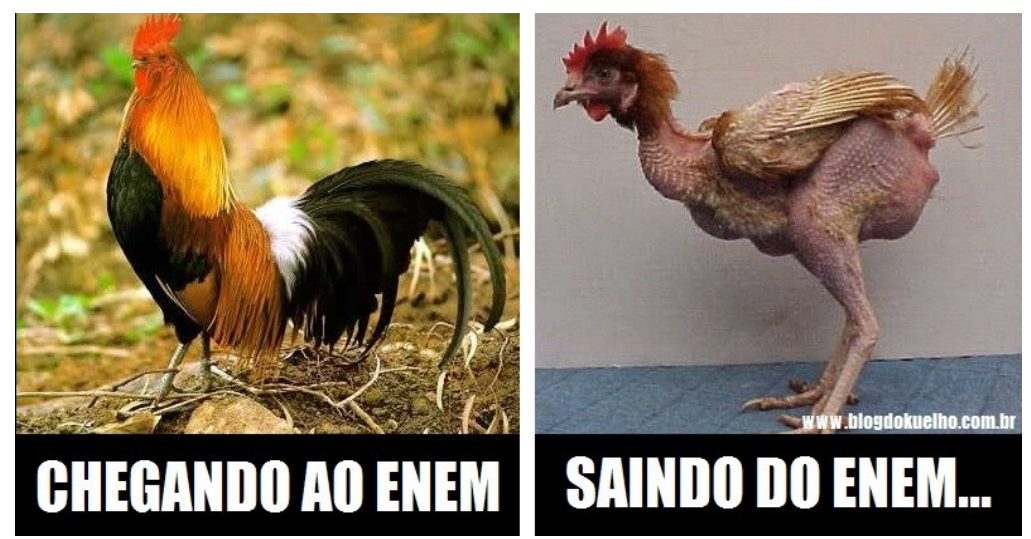

Fonte: Facebook, 2015

Fig. 5 - Meme retirado do Twitter relativo ao comercial Boticário

@umpoucodeironia: Antes da propaganda do Boticário / Depois da propaganda do Boticário
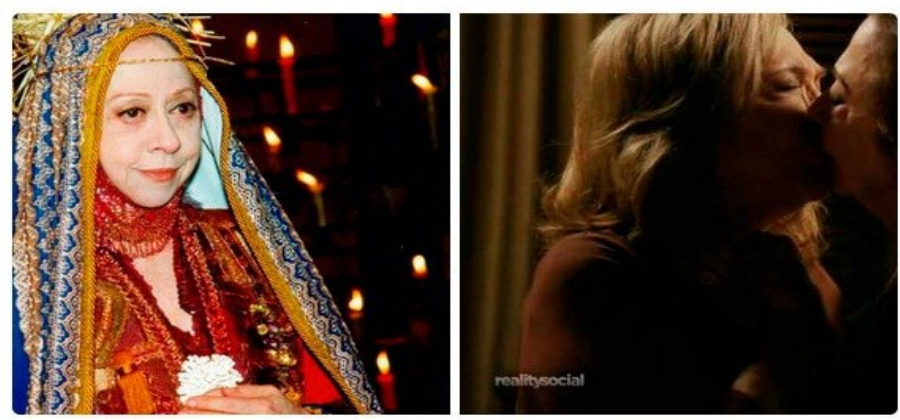

Fonte: Twitter, 2016

Texto Digital, Florianópolis, Santa Catarina, Brasil, v. 12, n. 2, p. 185-208, jul./dez. 2016. ISSNe: 1807-9288. 


\title{
4.1 Contribuições da TSSM na análise dos aspectos externos dos memes
}

\subsubsection{A cultura é essencial à compreensão e produção da leitura dos textos}

Kress, Leite-Garcia e van Leeuwen (2000), em relação ao primeiro aspecto analítico proposto, observam que a cultura de uma comunidade é preponderante no momento da construção dos textos multimodais, por isso, ela se torna determinante na construção do sentido desses textos, por parte dos leitores. As representações de imagens e textos não são destinadas apenas para popularizar uma informação ou fato, ou mesmo provocar humor. Elas são, sobretudo, construções que manifestam nossa relação com a sociedade que nos cerca, bem como o que ela representa.

Nessa perspectiva, Vieira (2007, p. 14) comenta que:

\begin{abstract}
As culturas produzem imagens próprias e sob esse enfoque apenas é que podemos interpretá-las. Cada nação constrói imagens e símbolos particulares. Nos Estados Unidos, as torres gêmeas simbolizavam o poder político e econômico norte-americano. Os povos constroem imagens afirmativas ou negativas a respeito de sua nação ou de outras nações. Para um estrangeiro, as imagens do Brasil são provavelmente as do carnaval e do futebol.
\end{abstract}

A formação cultural, por parte do leitor, é importante para que seja capaz de compreender o sentido produzido pelos memes, principalmente por meio das metáforas, visto que as condições sociais em que o indivíduo vive são essenciais para ler a imagem criticamente.

Constatamos, então, na Figura 4, a presença de dois participantes, e abaixo a frase que terá sentido unindo os dois modos comunicativos, o verbal e o não verbal. Como já dito, as imagens retratam o fato relativo à prova usada no sistema de seleção para o ingresso no ensino superior no Brasil. Cada país adota um sistema diferente para este caso, que pode se diferenciar do ENEM. A todos nós, brasileiros, não será desconhecido o evento do qual trata o meme, enquanto que para um estrangeiro será improvável ter conhecimento acerca do referido exame e a crítica por trás do meme. Isso pode ser comprovado a partir do que Meyer (apud SELVATICI, 2015, p. 
111) confirma: ao deparar-se com um texto, o "ser humano é então forçado a selecionar as informações, fazer conexões entre elas próprias e entre elas e seu conhecimento prévio". Quando o conhecimento cultural não está alcance do leitor, este é impossibilitado de compreendê-lo.

Tal observação também é parte da Figura 5. Trata-se de duas imagens, uma retirada da cena de um filme e outra de uma telenovela brasileira, que, aliadas à frase, criam um sentido que só será possível a sua compreensão por parte de quem conhecer os participantes retratados no meme, o que dificilmente acontecerá com as pessoas que não vivem no país ou, até mesmo, aqueles que, mesmo aqui morando, não tiveram conhecimento do fato. Vieira (2007) aponta que a leitura de um texto multimodal exige do leitor um preparo e conhecimento que vão além dos aspectos formais e abarcam o contexto situacional e, sobretudo, o cultural desses textos.

4.1.2 Os textos incorporam histórias sociais e culturais, contextos atuais e ação dos produtores dos signos sobre o contexto comunicativo

O segundo aspecto externo proposto por Kress, Leite-Garcia e van Leeuwen (2000) aponta que os acontecimentos atuais que, de certa forma, marcam a sociedade são os principais elementos necessários para a produção de um texto. Em relação aos memes percebemos, por exemplo, os fatos relacionados à Copa do Mundo, aos acontecimentos políticos e religiosos e aqueles que viralizam na web. Uma das características desse gênero, o fato de eles serem efêmeros, ocorre justamente por isso, agregarem situações envolvendo acontecimentos recentes. Logo, a maioria deles, em poucos dias, são descartados e substituídos por outros.

Assim, as análises evidenciam que o meme relacionado ao ENEM, embora seja efêmero, não é descartado definidamente, pois o processo do ENEM ocorre anualmente. Ou seja, o meme é intensamente compartilhado durante esse período específico do ano, assim finalizado, é postergado e seu uso não é convencional. O compartilhamento desse meme serve para caracterizar o processo de realização da prova, tida como cansativa e desgastante, por demandar do aluno 4-5 horas e meia para a resolução das questões. O fato é bastante discutido, principalmente nas 
redes sociais. Como resultado, diversos memes nesse sentido surgem para representar, crítica e humoristicamente esse episódio social.

No segundo meme, Figura 5, as mesmas características são válidas, porém, observamos que está em desuso, talvez, por muitos, esquecido, depois de quatro meses que foi intensamente compartilhado. Seu compartilhamento nas redes sociais, em maio e junho deste ano (2016), foi perfeitamente aceitável quando uma empresa de cosmético usou, para o dia dos namorados, um casal homossexual, fazendo referência a todos os tipos de casais. O fato gerou a revolta de um grupo social que alegou, dentre outras coisas, que o comercial poderia influenciar, principalmente as crianças.

Concordamos com Viera (2007), quando propõe que textos multimodais possuem marcas relacionadas à política, às causas sociais, às lutas de poder e ainda perpassa pelos interesses daqueles que os produzem. Pois, se retomarmos as duas figuras anteriores, perceberemos que elas não apenas revelam modos de expressão e sim, relações sociais, questões de poder e gênero.

\subsubsection{Produtores e leitores exercem poder em relação ao texto}

Em relação ao último ponto analítico, observamos que a ideologia, como organização de ideias que caracteriza os interesses de um grupo social, é um dos elementos que deve ser ressaltado ao analisar criticamente uma imagem. Vieira (2007) sustenta que as imagens multimodais não estão isentas e nem alheias às ideologias, e que as interpretações também podem ser feitas ideologicamente. Nesse sentido, entendemos que, tal como há diferentes ideologias entre os grupos sociais, na leitura de um texto, como os memes, também haverá diversas representações discursivas que podem divergir entre si, resultando em distintas interpretações.

Podemos verificar essa questão, especialmente, no segundo meme em análise, pois o posicionamento mostrado no comercial foi um dos principais temas de debate no 
momento em que foi veiculado. O produtor apropriou-se do fato, elaborando, assim, o meme.

Sobressai, na criação da imagem, a ideologia defendida por aqueles que simpatizaram com a informação transmitida pelo comercial. Esta aparece de maneira não tão explícita, por meio de duas cenas consagradas na dramaturgia brasileira e realizadas pela atriz Fernanda Montenegro. As cenas têm personagens e contextos totalmente diferentes: a primeira foi retirada do filme O Auto da Compadecida (2000), onde a atriz interpretou a personagem Nossa Senhora da Compadecida, sendo esta vista totalmente boa, pura e santa; ao passo que a segunda foi retirada da novela Babilônia (2015), onde a atriz viveu uma personagem homossexual e na cena beijava outra atriz (Natália Timberg). As características das duas personagens, de Fernanda Montenegro, foram elencadas para que o leitor percebesse o contraste entre ambas.

Percebem-se dois objetivos que talvez o produtor do meme esperasse alcançar com o conteúdo do gênero: o primeiro, relacionar o argumento sobre o comportamento dos personagens do comercial, que poderia ser influenciador, como algo sem nexo, assim como as cenas de ficção mostradas, que servem apenas como artifício para mostrar a realidade da sociedade; o segundo, colocar os que renegaram o comercial como pessoas santas e benévolas, tal como a primeira personagem, e que poderiam, rapidamente, perder essas características por conta do comercial. $\mathrm{O}$ meme, assim, conduz a ideia de que antes do comercial da marca de cosméticos as pessoas eram vistas como "santas" e talvez até puras; depois, há uma dada "liberação", e a mesma participante, personagem da atriz Fernanda Montenegro, torna-se homossexual. Porém, o produtor do texto não toma partido, quem o faz são os observadores e visualizadores do gênero.

Dessa forma, acedemos com Selvatici (2015, p. 109) quando afirma que "é o produtor que faz as escolhas que deseja ver transmitidas e, consequentemente, os significados sociais que resultam dessas escolhas". Contudo, essa ideologia presente no meme poderá não ser a mesma despertada pelo leitor. Selvatici (2015) aponta também que o leitor de um texto escolhe a forma mais conveniente a si para 
interpretá-lo. Portanto, analisamos o fato mais previsível que deva ocorrer no momento da leitura por parte dos leitores que tiveram uma reação negativa e daqueles com reação positiva. O humor, certamente, é a reação a ambos os casos. Logo após, a reação mais esperada, em relação ao primeiro, provavelmente seja a não leitura crítica do meme, visto que, caso ocorra a interpretação a fundo, observará a ironia e a quem ela é destinada. Ou ainda, este poderá lê-lo como um aspecto positivo, não entendendo/interpretando corretamente a ironia, já que ela não fica totalmente clara. Enquanto que o segundo leitor, dedicará mais tempo nessa análise e poderá assimilar a ideologia que se faz presente. Assim constatamos que tanto os produtores quanto os leitores de um texto multimodal exercem poder sobre eles.

\subsection{A contribuição da GDV para a leitura interna dos memes}

A Gramática do Design Visual, como já abordado anteriormente, dedica-se às análises dos textos multimodais. A partir de então, apresentaremos os aspectos relacionados ao funcionamento interno dos memes, que podem nos auxiliar a observar as ideologias e as críticas por trás destes.

A GDV, de Kress e van Leeuwen, oferece categorias analíticas relacionadas às metafunções da linguagem. A primeira dela, a representacional, focaliza as estruturas visuais, bem como nos participantes representados nas imagens, aponta para a classificação, a categorização e a análise desses personagens. Kress e van Leeuwen observaram que, assim como na linguagem verbal - como em um discursoas pessoas que produzem e aquelas a quem se destinam os textos são estudadas. Nas imagens, "o que é realizado na linguagem verbal por palavras da categoria de verbos de ação, é nas imagens realizado por elementos que podem ser formalmente definidos por vetores" (KRESS e VAN LEEUWEN, 2006, p. 45). Basicamente, esta metafunção se preocupa em observar o envolvimento dos participantes nas imagens, podendo constituir um metafunção representacional narrativa, caso esteja o participante em movimento ou com ideia que assemelhe tal ato; caso esteja estático, parado e sem sugerir movimento, será constituída metafunção representacional conceitual. Na análise dos memes, observamos que, no primeiro 
meme, ambos os participantes se articulam de modo estático (conceitual), o mesmo ocorre com a primeira imagem do segundo meme, ao passo que na segunda imagem, as participantes se beijam, ficando clara a ideia de movimento (narrativa).

Em relação à segunda metafunção, a interativa, o foco é na relação/interação que pode ocorrer entre o participante representado (PR) e o observado/leitor, doravante participante interativo (PI). Aspectos como a direção do olhar e o posicionamento do PR, bem como, a atitude do PI são analisados. Ao considerar esse prisma, em ambos os memes (Figuras 4 e 5), os dois participantes mantêm uma relação distante e não envolvente com o observador, por não terem o olhar direcionado a ele e ainda pelo posicionamento distante na imagem. Já no segundo, as participantes das duas imagens mantêm uma relação mediana com o PI, pois aparecem em uma distância media que, conforme Kress e van Leeuwen (2006), é o participante representado da cintura para cima. Percebemos também que os olhares das PRs não focalizam diretamente o observador.

Concluindo, a metafunção composicional analisa o ambiente da imagem, sua composição e arranjos para criar sentido num todo, com isso, é importante observar as luzes, as cores destacadas, a organização dos textos, as molduras. Em suma, a organização em geral da imagem é levada em consideração. Essa metafunção é subdividida em: valor informativo, saliência e enquadramento. Verificando cada uma nos dois memes analisados, observamos em relação ao enquadramento que são bastante coerentes na organização, trazendo primeiro uma imagem, em seguida a outra, para dessa forma confrontar o leitor, e o texto verbal aparece sempre dialogando com as imagens. Sobre esse fato, adentramos nos valores de informações da imagem. Kress e van Leeuwen (2006) apontam que em relação às imagens ocidentais o lado direito tende a aparecer a imagem que denominam dado e o esquerdo, o novo. Ambos os memes (Figuras 4 e 5), quanto ao Dado (conhecido), aparece um galo bonito e robusto, como conhecemos; quanto ao Novo (revelado), apresenta um animal, frágil e debilitado, similar ao que ocorre com os estudantes ao término da prova do ENEM, visto que saem muitas vezes fragilizados e cansados. O mesmo ocorre com o segundo meme, Figura 5, o jogo nas imagens revela o primeiro quadro como mais aceitável socialmente, mais conhecido, ao 
passo que o segundo conduz a uma nova representação, desconhecida e talvez inédita. Abaixo, na Tabela 2, sintetizamos as análises colocadas e baseadas na teoria de Kress e van Leuwen.

Tabela 2 - Os memes analisados de acordo com metafunções da GDV

\begin{tabular}{|c|c|c|}
\hline $\begin{array}{c}\text { METAFUNÇÕES } \\
\text { GDV }\end{array}$ & O QUE É? & COMO SE APLICAM NAS IMAGENS: \\
\hline 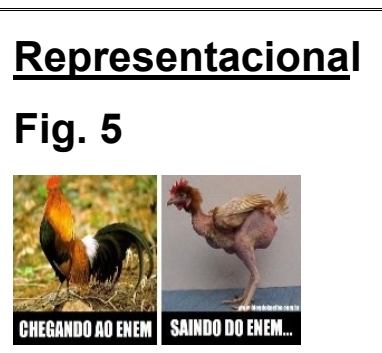 & \multirow{2}{*}{$\begin{array}{l}\text { Analisa aspectos } \\
\text { referentes aos } \\
\text { personagens } \\
\text { presentes nas } \\
\text { imagens, bem como } \\
\text { suas } \\
\text { representações e } \\
\text { comportamentos. }\end{array}$} & $\begin{array}{l}\text { Figura 4: Imagem conceitual, pois } \\
\text { ambos os participantes transmitem a } \\
\text { mensagem desejada de maneira } \\
\text { estática. }\end{array}$ \\
\hline 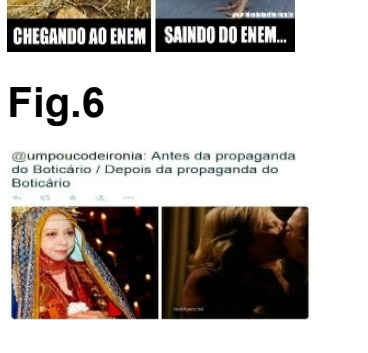 & & $\begin{array}{l}\text { Figura 5: A primeira imagem do meme } \\
\text { constitui como conceitual ao passo que } \\
\text { na segundo imagem, as participantes } \\
\text { se beijam, ficando clara a ideia de } \\
\text { movimento (narrativa). }\end{array}$ \\
\hline \multirow{2}{*}{$\begin{array}{l}\text { Interativa } \\
\text { Fig. } 5\end{array}$} & \multirow{2}{*}{$\begin{array}{l}\text { Verifica a relação e } \\
\text { interação entre os } \\
\text { participantes das } \\
\text { imagens ao } \\
\text { observador }\end{array}$} & $\begin{array}{l}\text { Figura 4: Os dois participantes mantêm } \\
\text { uma relação distante e não envolvente } \\
\text { com o observador, por não terem o } \\
\text { olhar direcionado a ele e ainda pelo } \\
\text { posicionamento distante na imagem. }\end{array}$ \\
\hline & & $\begin{array}{l}\text { Figura 5: As participantes das duas } \\
\text { cenas do meme mantêm uma relação } \\
\text { mediana com quem as observa, pois } \\
\text { são mostradas da cintura para cima. } \\
\text { Percebemos também que os olhares } \\
\text { das PRs não focalizam diretamente o } \\
\text { observador. }\end{array}$ \\
\hline
\end{tabular}




\begin{tabular}{|c|c|c|}
\hline 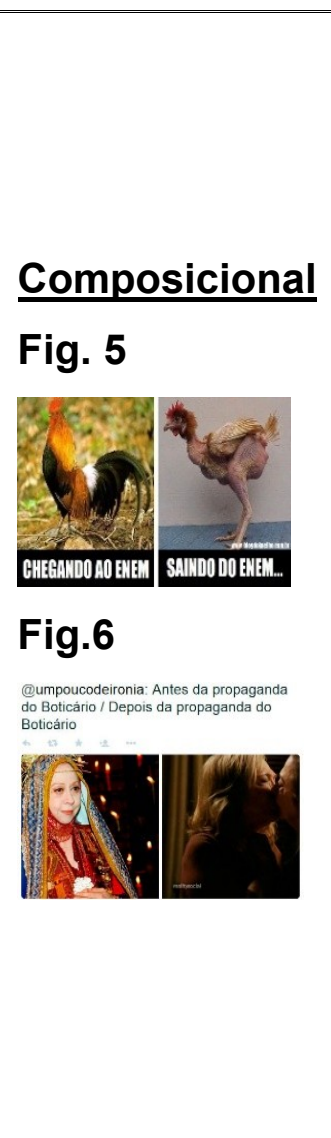 & $\begin{array}{l}\text { Trata da } \\
\text { estruturação e } \\
\text { composição dos } \\
\text { elementos e } \\
\text { participantes } \\
\text { elencados nas } \\
\text { imagens. }\end{array}$ & $\begin{array}{l}\text { Figura 4: A estrutura do meme, as } \\
\text { molduras e linhas divisórias dão um } \\
\text { aspecto coesivo à imagem. À direita } \\
\text { tem-se um galo bonito e robusto, como } \\
\text { conhecemos trivialmente (dado), em } \\
\text { seguida apresenta-se um ser frágil e } \\
\text { debilitado, tal como ocorre com os } \\
\text { estudantes que prestam o exame } \\
\text { (novo). } \\
\text { Figura 5: O mesmo ocorre com o } \\
\text { segundo meme, o jogo nas imagens, } \\
\text { aponta que a primeiro é a mais } \\
\text { aceitável socialmente, mais conhecida, } \\
\text { ao passo que o segundo é a figura } \\
\text { nova, aquela mais desconhecida, } \\
\text { inédita. }\end{array}$ \\
\hline
\end{tabular}

Fonte: Elaborada pelos autores

\section{Considerações Finais}

Observamos que tanto a linguagem verbal quanto a visual possibilitam analisar os participantes presentes nos memes, suas diferentes relações com os leitores, sua estrutura e organização, comum a todos, para no fim efetivar-se o sentido. Além disso, verificamos o quanto esses textos carregam ideologias e conceitos que são introduzidos no momento da produção, mas nem por isso são aceitos e interpretados da mesma maneira pelos leitores que precisam de um conhecimento cultural e prévio para compreendê-los.

Com isso, as análises revelam que esse novo gênero, apesar de recorrente, em muitas mídias, suscita investigações quanto à sua relevância por congregar uma diversidade discursiva, cujos participantes e produtores muitas vezes são desconhecidos ou não revelados, principalmente, na questão do multiletramento se considerarmos que esse gênero digital e muitos outros são consumidos não só por 
adultos, mas também pelos adolescentes. Assim, ter uma leitura verbal e visual possibilita melhor compreender as práticas sociais que perfazem a sociedade moderna e que estão refletidas nas mídias como um todo.

\section{MEMES GO BEYOND HUMOR: A MULTIMODAL READING FOR CONSTRUCTION OF MEANING}

ABSTRACT: The advent of new digital media has brought to the cybernetic environment innovative ways of communicating and using the language, making it more dynamic and visual. In parallel to this, new genres arise as a result of changes in cyberspace. Meme is one of these and stands out for its accentuated presence on social networks. Assessing its importance in the current context, we seek to analyze the discursive visual configuration present in this digital genre. We took as object of analysis two memes, chosen because they have been widespread on social networks and for conducting social practices about contemporary life. The analytical categories used are those of the Theory of Multimodal Social Semiotics (TMSS): The assumptions of Kress, Leite-Garcia and van Leeuwen (2002) regarding the semiotic conception of the multimodal texts in their external aspects were adopted, considering the moment of production, an influence of the reader, a culture and the social context; As well as the Grammar of Visual Design (GVD), theory developed by Kress and Leeuwen (2006), that analyzes the representational, interactive and compositional meanings, concerning the construction of sense, both humorous and critical, considering the participants presented in the images, the interaction with the observer and the image composition. The analysis demonstrated that these genres are widespread in social networks, serving both for the dissemination of everyday topics and for specific criticism about situations experienced by many people.

KEYWORDS: Digital Genres. Multimodality. Memes. Visual Speech.

\section{Referências}

BAKHTIN, M. O problema dos gêneros dos discursos. In: Estética da criação verbal. Tradução de Paulo Bezerra. São Paulo: Martins Fontes, 2003.

BAUMAN, Z. Modernidade Líquida. Tradução de Plínio Dentzien. Rio de Janeiro: Zahar, 2001.

BRASIL, Ministério da Educação. Parâmetros Curriculares Brasileiros. Brasília, 2006.

CANDIDO, E. C. R; GOMES, N. T. Memes - uma linguagem lúdica. Revista Philologus, Rio de Janeiro, ano 21, n. 63, p. 1293-1303, set./dez., 2015.

CARVALHO, N; KRAMER, R. A linguagem do Facebook. In: SHEPHERD, T. G; SALIĖS, T. Linguística da Internet. São Paulo: Contexto, 2013. 
COURI, Aline. Comunicação e artes EC1 2012-2. 2013. Disponível em: <https://comunicacaoeartes20122.wordpress.com/2013/01/14/arte-concretista/> Acesso em: 01 ago. 2016.

DIONÍSIO, A. P. Gêneros textuais e multimodalidade. In: KARWOSKI, A. M.; GAYDECZKA, B.; BRITO, K. S. (Orgs.). Gêneros textuais: reflexões e ensino. 4. ed. São Paulo: Parábola Editorial, 2011.

HALLIDAY, M. A. K. An Introduction to Functional Grammar. London: Edward Arnold, 1994.

HALLIDAY, M. A. K.; MATTHIESSEN, C. An Introduction to Functional Grammar. 3. ed. Londres: HodderEducation, 2004.

KENSKY, V. M. Tecnologias e ensino presencial e a distância. Campinas, SP: Papirus, 2003.

KRESS, G. Literacy in the new media age. London/NY: Routledge, 2003.

KRESS, G; LEITE-GARCIA, R; van LEEUWEN, T. Semiótica discursiva. In: El discurso como estrutura y processo: estúdios sobre el discurso. Una introducción multidisciplinaria. Compilado por Teun van Dijk. Espanha: Gedisa Editorial, 2000.

KRESS, G.; VAN LEEUWEN, T. Reading images: the grammar of visual design. London: Routledge, 2006 [1996].

MARCUSCHI, L. A. Produção textual, análise de gênero e compreensão. São Paulo: Parábola, 2008.

MARTINO, L. M. S. Teoria das mídias digitais: linguagens, ambientes e redes. 2. ed. Petrópolis: Editora Vozes, 2015.

MCLUHAM, M. Os meios de comunicação como extensões do homem. Trad.: Décio Pignatari. São Paulo: Cultrix, 2007 [1969].

NASCIMENTO, R. G; BEZERRA, F. A. D; HEBERLE, V. M. Multiletramentos: iniciação à análise de imagens. Linguagem e Ensino, Pelotas, v. 14, n. 2, p. 529-552, jul./dez. 2011.

PRIBERAM, Dicionário on-line da língua portuguesa. Busca: meme. 2016 Disponível em: <http://www.priberam.pt/DLPO/meme> Acesso em 27/07/2016.

RAJAGOPALAN, K. Como o internetês desafia a Linguística. In: SHEPHERD, T. G; SALIĖS, T. (Orgs.) Linguística da Internet. São Paulo: Contexto, 2013.

SOARES, N. M. M. O signo visual e a metáfora multimodal. Revista Recorte, Belo Horizonte, UniCor, v. 13, n. 2, jul./dez. 2016. 
VIEIRA, J. A. Novas perspectivas para o Texto: uma visão multissemiótica. In: VIERA, J. A. et al. Reflexões sobre a língua portuguesa - uma abordagem multimodal. Petrópolis: Editoras Vozes, 2007.

Recebido em: 14/09/2016.

Aceito em: 07/12/2016. 